\title{
FAKTOR EKSTERNAL DAN INTERNAL STRATEGI PENGINJILAN MENGHADAPI PENGANIAYAAN DI SUKU TERABAIKAN
}

\author{
Elizabeth Situmorang \\ Sekolah Tinggi Teologi Soteria Purwokerto \\ Jl. Raya Barat, Ketenger, Kec. Baturraden, Kab. Banyumas, Jawa Tengah \\ E-mail: bortung97@gmail.com
}

\begin{abstract}
ABSTRAK: Strategi penginjilan merupakan sebuah rencana yang wajib dilakukan sebelum bermisi, mengingat berbagai kasus penganiayaan yang menimpa beberapa penginjil maupun masyarakat Indonesia. Khususnya di daerah suku terabaikan seperti Papua, kini semakin marak terjadinya kasus penganiayaan. Hal ini menimbulkan berbagai luka fisik maupun psikis bagi sebagian kelompok dan yayasan penginjilan. Beberapa penginjil melakukan sebuah terobosan baru untuk meningkatkan mutu terhadap penginjilan yang ada di daerah terabaikan. Beberapa strategi telah disusun sebagai upaya untuk mencerminkan kepribadian Kristus. Melalui metode yang berorientasi pada studi pustaka, tulisan ini menunjukkan bahwa dengan adanya strategi penginjilan yang berorientasi pada faktor internal maupun eksternal, diharapkan mampu untuk menghadapi penganiayaan yang terjadi dalam bermisi. Oleh karena itu, strategi penginjilan harus direncanakan, dipahami serta digunakan sebagai upaya berjagajaga untuk menghadapi kasus penganiayaan yang terjadi.
\end{abstract}

Kata Kunci: kristus; misionaris; papua; penganiayaan; penginjilan; rendah hati; strategi

\section{THE EXTERNAL AND INTERNAL FACTORS ON STRATEGIES FOR EVANGELISM FACING PERSECUTION IN NEGLECTED TRIBES}

\begin{abstract}
The evangelism strategy is a plan that must be done before the mission, considering the various cases of persecution experienced by several evangelists and the people of Indonesia. Especially in neglected tribal areas, such as Papua, cases of persecution are increasingly widespread. This has caused various physical and psychological injuries to some evangelistic groups and foundations. Some evangelists make a new breakthrough to improve the quality of evangelism in neglected areas. Several strategies have been devised in an attempt to reflect the personality of Christ. By utilizing library research, this article shows that with the evangelism strategy oriented on internal and external factors, it is expected that the persecution that occurs in the mission can be faced. Therefore, evangelism strategies must be planned, understood, and used as a precaution to deal with persecution cases.
\end{abstract}

Keywords: christ; missionary; papua; persecution; evangelism; bumble; strategy 


\section{PENDAHULUAN}

Akhir-akhir ini, beberapa penginjil menjadi korban penganiayaan di daerah pelosok Papua. Misalnya serangan terhadap pesawat Twin Otter Mission Aviation Fellowship (MAF) di Desa Pagamba, Distrik Biandga, Intanjaya, 6 Januari 2021. Pesawat misionaris yang hendak bermisi tersebut habis terbakar. Hal ini telah mengakibatkan beberapa penginjil tewas (Tim SINDOnews, 2021). Selain itu, rusaknya fasilitas-fasilitas yang diberikan yayasan misionaris dalam menjalankan misi menjadi penghambat para penginjil dalam mengerjakan pelayanannya kepada masyarakat Papua yang memberontak atau biasa disebut KKB (Kelompok Kriminal Bersenjata). Kelompok ini merupakan sebuah kelompok yang menggunakan senjata secara ilegal dengan tujuan untuk memisahkan diri dari kesatuan NKRI (Negara Kesatuan Republik Indonesia). Kelompok ini juga biasa disebut sebagai Organisasi Papua Merdeka (OPM), Tentara Pembebasan Papua Barat (TNPPB), dll. (Pane, 2006). Kelompok ini ternyata mengikat semua orang tidak hanya menyerang beberapa penginjil, tetapi juga aparatur negara, masyarakat sipil dan lainnya.

Sebelum itu, penganiayaan terhadap orang-orang percaya juga terjadi pada abadabad awal, ketika Kaisar Nero (sekitar tahun 60 M) menangkap orang-orang percaya dan melemparkan mereka ke dalam stadion untuk dimakan singa-singa (Liauw, 1999, p. 27). Murid-murid Yesus berada di tengah-tengah dunia yang jahat dalam menghadapi berbagai macam penganiayaan yang terus menerus mengancam keberadaan mereka.

Karena itu, dalam tulisannya Natan Silalahi mengatakan bahwa, penting untuk memahami dengan benar firman Tuhan tentang penganiayaan yang dialami orang Kristen agar menjadi orang yang dewasa secara rohani dan mampu menanggapi penganiayaan dengan takut akan Tuhan. Ini adalah harapan yang dapat digunakan oleh orang percaya hari ini
(Silalahi, 2019, p. 3).

Memang benar yang dikatakan oleh Natan Silalahi tentang pentingnya pemahaman akan firman Tuhan menolong kita menjadi orang percaya yang semakin bertumbuh di dalam Tuhan. Namun di samping itu juga diperlukan tindakan nyata sebagai sikap antisipasi dalam menghadapi penganiayaan. Memang sejatinya orang yang percaya kepada Kristus harus melakukan perbuatan kasih tetapi kasih juga mengajarkan manusia untuk membuat strategi dikala kondisi mencengkam seperti terjadinya penganiayaan dan pembunuhan terhadap para penginjil yang hendak membela imannya.

Dengan demikian penulis menambahkan sebuah strategi yang dapat membantu untuk digunakan dalam menghadapi penganiayaan yang akan terjadi di lapangan sebagai langkah awal untuk menjadi pengikut Kristus yang siap sedia baik di lingkungan yang nyaman maupun zona liar.

Insiden ini hanyalah salah satu contoh bagaimana para misionaris yang diutus kerap kali menjadi sasaran utama dari kelompok yang tidak bertanggung jawab. Apabila hal ini sering terjadi maka kemungkinan dapat menyebabkan trauma atau adanya rasa takut dan khawatir untuk pergi bermisi. Kondisi fisik dan psikis yang tidak stabil serta adanya gangguangangguan khusus yang sulit diperbaiki serta merusak sistem syaraf otak akan menimbulkan perubahan sifat dan sakit jiwa (Harefa, 2020). Sehingga beberapa para misionaris menjadi enggan mengirim personil baru untuk menyebarkan Injil dan membantu masyarakat yang membutuhkan pekabaran Injil.

Kasus-kasus seperti ini menjadi perhatian yang penting bagi orang Kristen, gereja, yayasan dan lembaga yang bergerak di bidang misi, untuk merencanakan dan melatih penginjil supaya lebih matang mempersiapkan diri menghadapi situasi yang tidak terduga. Berbagai tulisan-tulisan menarik untuk dibahas dalam metode penginjilan. Oleh karena itu, 
dibutuhkan sebuah strategi agar para penginjil atau misionaris dapat dengan aman mengabarkan Injil serta membantu masyarakat untuk melayani sesama.

Makalah ini melihat ada dua faktor strategi yang menentukan berhasilnya penginjilan, yaitu faktor internal dan eksternal, sehingga dibutuhkan strategi mempersiapkan diri penginjil secara personal, dan strategi mempersiapkan ladang penginjilan secara sosial masyarakat. Strategi internal belajar dari pribadi Kristus yang mencakup: kerendahan hati, penyangkalan diri, dan berjaga-jaga, sedangkan strategi eksternal membangun kesetaraan sosial masyarakat.

\section{METODE}

Metode penelitian yang dipaparkan oleh penulis merupakan metode kajian literatur yang berfokus kepada pandangan beberapa tokoh penginjilan yang menjadi sumber untuk menulis. Riset sejenis ini juga disebut riset kepustakaan (library research). Penelitian kepustakaan, yang biasa dikenal dengan penelitian dokumen, adalah serangkaian tindakan yang berkaitan dengan strategi penyimpanan data perpustakaan, peninjauan, pencatatan, dan pemrosesan bahan yang dicari (Zed, 2008, p. 3). Alasan yang membuat penulis melakukan penelitian menggunakan kajian pustaka yaitu buku merupakan bukti sumber utama yang memadai untuk mencari sebuah informasi, pembelajaran mandiri serta bahan untuk membuat karya tulis akademik dan khotbah.

Strategi Penginjilan dengan melihat faktor internal dan eksternal efektif untuk menjalankan misi pekabaran Injil di daerah terabaikan. Serta menangani bagaimana menghadapi keadaan yang tidak terduga seperti penganiayaan yang terjadi pada para calon misionaris maupun penginjil. Untuk membuktikan argumen tersebut penulis akan melakukan survei literatur terhadap tulisan atau karya tulisan dari D. W. Ellis dalam bukunya yang berjudul Metode Penginjilan. Buku ini membahas dari awal ketika seorang menjadi penginjil sampai praktik langsung di lapangan dalam melakukan penginjilan. Dibekali dengan pengalaman-pengalaman beberapa tahun terlibat dalam upaya penginjilan di beberapa daerah di Indonesia. Disertai juga dengan catatan-catatan hasil pengalaman dan pengamatan selama beberapa tahun yang dapat berguna untuk memperoleh strategi penginjilan yang dapat diaplikasikan dan dipelajari.

Penulis juga menginput komentar dari Saints atau Bapa-bapa gereja yang lebih awal menjalani kehidupan penganiayaan yang berat baik dengan melihat kaidah dan ajaran yang disampaikan memuat sebuah komentar yang berhikmat dari kata-kata tersebut. Penulis telah mengkaji sebuah buku yang menjadi pedoman untuk menulis di antaranya buku Philokalia yang memuat berbagai komentar Bapa-bapa gereja tentang kehidupan Monastic atau biara yang menjalani kehidupan askese yang jauh dari kenyamanan dunia bahkan sangat menderita.

\section{HASIL DAN PEMBAHASAN}

\section{Strategi Eksternal: Menghadapi Penganiayaan}

Penganiayaan adalah sebuah perbuatan bengis yang dilakukan oleh raja pada zaman dahulu kepada para budaknya dengan seenaknya atau sewenang-wenang (Moeliono, 1988, p. 39). Penganiayaan juga berarti sebuah tindakan yang tidak terpuji dan tidak manusiawi baik di hadapan Tuhan maupun manusia. Elvin Atmaja Hidayat menyatakan tiga kejelekan yang dapat menyebabkan penganiayaan seperti, pertama, kejelekan fisik yang berhubungan dengan jasmani. Kedua, kejelekan metafisik yang disebabkan oleh bencana alam yang mengakibatkan penderitaan. Terakhir, kejelekan yang dapat dilihat dari perbuatan buruk orang maupun kelompok (Hidayat, 2016, pp. 285308). Penganiayaan yang menimpa para misionaris, khususnya di daerah suku terabaikan menjadi pergumulan dan perhatian beberapa 
golongan yang bergelut di bidang ini. Meski demikian, hal ini tidaklah menjadi kendala beberapa penginjil untuk tetap setia memeritakan Injil bagi mereka yang belum memperoleh Injil keselamatan. Injil merupakan kabar gembira yang ditujukan kepada orangorang yang menginginkan anugerah Tuhan supaya dapat disembuhkan dari setiap pelanggaran yang mengikat diri kepada maut. Salah satu cara untuk memuliakan Allah adalah dengan mengabarkan Injil. Dengan cara demikian murid-murid Kristus dapat memberitakan Injil kepada semua orang. Keberanian itu muncul ketika mereka telah menerima janji keselamatan hidup kekal dari Allah melalui turunnya Roh Kudus (Rm. 1:5).

Langkah awal yang harus diperhatikan untuk menjadi seorang penginjil atau misionaris yaitu melalui sebuah panggilan dari Allah yang memiliki kerinduan hati untuk melayani. Panggilan yang dimaksud adalah sebuah ketaatan yang akan sangat menyiksa diri untuk melakukan kehendak Allah dengan berpedoman kepada kasih karunia Allah. Thomas Hale menegaskan, "Menjadi seorang penginjil dimulai dari sebuah panggilan. Saudara tidak memilih untuk menjadi seorang misionaris. Satu-satunya pilihan yaitu apakah saudara ingin menaatinya" (Hale, 1995, p. 16). Ketaatan bukanlah hal yang mudah untuk dikerjakan. Dibutuhkan ketulusan dan kerendahan hati untuk menyampaikan firman yang menjadi pesan cinta dari Allah. Misi gereja tidak dapat terpisah dari Nasihat Agung Kristus. Melalui denominasi gereja, Amanat Agung dikaitkan dengan tanggung jawab misionaris, termasuk yang dipahami sebagai menginjil menghasilkan pribadi yang akan diselamatkan (Manurung, 2020).

Inti dari Amanat agung yang sering didengar baik di gereja maupun seminarseminar adalah memberitakan Injil ke seluruh dunia. Hal ini merupakan cara yang kita lakukan untuk mengasihi Allah. (Gal. 5:13) mengatakan bahwa mengasihi bukan hanya sebuah perasaan melainkan sebuah pelayanan (Ellis, 2005, p. 13). Pernyataan ini membuat gairah dari dalam diri memuncak sehingga ingin segera menginjil. Namun, ada hal-hal yang harus dipikirkan ketika hendak pergi menginjil. Penting bagi seorang penginjil atau misionaris untuk menyusun strategi agar bisa mengatur dan memahami kondisi dan ruang lingkup daerah yang akan ditargetkan untuk menginjil.

Dengan adanya penginjil-penginjil yang diutus di daerah-daerah terpencil akan sangat membantu masyarakat untuk mengenal pribadi Allah serta dapat menjadi sebuah obat untuk mereka yang mengalami penganiayaan atau kesakitan batin maupun psikis (Sills, 2008, p. 145). Perencanaan sangat perlu dilakukan karena menghasilkan sebuah persiapan yang dapat disusun secara sistematis. Seperti yang dijelaskan C. Peter Wagner, ada sepuluh langkah dalam menyusun rencana misi penginjilan:

1. Memutuskan penginjilan yang akan dilaksanakan,

2. Memilih personil yang akan dijadikan target,

3. Memilih usaha yang digunakan saat bermisi,

4. Memutuskan fasilitas dan strategi misi yang akan dipakai,

5. Memilih menjalin relasi yang digunakan,

6. Memperkirakan pencapaian yang diinginkan,

7. Mengerjakan masing-masing pekerjaan,

8. Menciptakan strategi,

9. Mengerjakannya,

10. Menilai kembali hasil pekerjaan (Wagner, 1996, pp. 81-87).

Strategi yang telah direncanakan sebaiknya dipertimbangkan terlebih dahulu sebelum dikerjakan. Hal ini berguna sebagai bahan evaluasi diri sehingga dapat mengetahui risiko yang ada dan akan terjadi ke depannya. Penting untuk diketahui adanya unsur-unsur terpenting dalam mengabarkan Injil, seperti: 
Fokus warta yaitu pribadi Kristus sebagai penyelamat; Isi warta tentang iman dan pertobatan; Warta berserah kepada Kristus sebagai Allah; Informasi warta serta metodenya sesuai dengan kondisi, pemahaman, level pemahaman dan konteks historis pendengar (Ellis, 2005, p. 115).

Unsur-unsur tersebut perlu diperhatikan sebagai acuan dasar dalam mengabarkan Injil. Strategi yang dapat diterapkan untuk mengabarkan Injil yaitu dengan melihat langsung contoh teladan Penginjil yang baik, yaitu Tuhan Yesus Kristus. Adapun strategi penginjilan Kristus menyangkut pribadi-Nya secara internal, yaitu sikap hati dan relasi personal-Nya dengan Bapa. Oleh sebab itu, strategi pertama adalah dimulai dari diri sendiri.

\section{Ubah Hati untuk Rendah Hati}

Sebuah rencana yang matang dapat dipakai untuk mengawali sebuah komunikasi yang konsentrasinya dapat diminati oleh para pendengar Injil (Dornan \& Maxwell, 1996, p. 142). Namun, terkadang sifat ego mendominasi diri untuk menonjolkan bahkan memamerkan kualitas diri atau materi kepada orang-orang untuk menarik minat para pendengar Injil. Hal ini menimbulkan sebuah rasa iri dan kecemburuan sosial kepada para penginjil, sehingga menimbulkan perpecahan bahkan penganiayaan.

Penganiayaan terjadi karena adanya kesalahan menilai sikap atau penampilan seseorang. Penganiayaan bukanlah kekalahan atau bahkan hukuman, tetapi sebuah kemenangan. Rintangan dan penderitaan yang harus dilalui oleh seorang murid Kristus tentu sudah diketahui Allah. (Nessy, 2021). Hal ini dapat diatasi dengan memiliki kerendahan hati untuk menghargai sesama suku, ras, dan budaya.

Sikap kerendahan hati dapat dilihat di dalam diri Kristus. Ketika Ia mau menerima kekurangan manusia yang berdosa. Bahkan dengan meninggalkan kemuliaan-Nya di surga, Kristus mau menahan kesakitan serta hidup menderita seperti manusia. Dalam pemberitaan Injil, Kristus menghadapi berbagai tantangan dan rintangan. Hal itu merupakan sebuah pertunjukan dan rencana Allah akan kasih-Nya yang begitu besar kepada manusia saat mereka belum percaya kepada Anak Allah.

Penganiayaan yang dihadapi oleh Kristus berupa penganiayaan yang dialami baik secara psikis dan fisik. Secara psikis, Kristus telah difitnah dengan segala kebohongan yang diutarakan para imam untuk menghukum Kristus supaya dihukum mati. Kemudian Dia juga dianggap telah menghujat Allah dengan mengakui diri-Nya adalah seorang Putra Allah. Menyikapi hal itu, Kristus hanya bisa diam dan membenarkan diri bahwa Ia memang seorang putra Allah yang akan duduk di sebelah kanan Allah (Mat. 26:63-64). Sikap yang ditunjukkan Kristus menunjukkan Ia memiliki kerendahan hati dan tidak langsung menghakimi orangorang yang bersaksi palsu tentang dirinya (Mat. 26:59). Penganiayaan fisik yang dialami Kristus, dipukuli sampai mati di kayu salib, adalah akibat kesalahan yang sesungguhnya tidak pernah Ia lakukan. Hal ini merupakan bentuk kekesalan orang-orang yang membenci Kristus pada saat itu (Mat.26:67).

Sebuah sikap kerendahan hati yang ditunjukkan Kristus tidak lepas dari sebuah rasa cinta yang diselimuti luka untuk menyelamatkan manusia. Dibutuhkan sebuah dispassion atau ketersapihan nafsu untuk mencapai kerendahan hati. Menjadi pribadi yang takut akan Allah adalah kunci mencapai kerendahan hati. Disspasion (mematikan nafsu jahat) akan membawa seseorang kepada cinta Tuhan, yang dicapai melalui harapan manusia kepada Tuhan. Kita tidak dapat memiliki cinta tanpa ketenangan, dan kita tidak dapat memiliki ketenangan tanpa pengharapan Tuhan. Tanpa kesabaran, kerendahan hati, dan ketaatan, kita tidak dapat memiliki harapan.

Seorang penginjil yang telah dipersiapkan untuk mengabarkan Injil harus memiliki sikap yang demikian. Seorang penginjil harus sudah 
siap untuk meninggalkan semua fasilitas yang dulu menjadi kenyamanan bagi diri sendiri. Walaupun demikian, sejumlah kandidat tanpa pola pikir yang fleksibel tidak bersedia melayani di tempat yang tidak mereka pilih sendiri. Namun, inilah yang Henry Jessup tulis, "Orang yang tidak bersedia untuk pergi ke mana saja sebaiknya tidak pergi. Harus ada kerendahan hati"(Jessup, 1901, p. 14).

Kerendahan hati dapat dimulai dari memberikan senyuman kepada para pendengar, serta menjalin komunikasi dan hubungan yang baik kepada suku yang akan diberitakan Injil. Tanpa pengendalian diri, tidak akan ada kesabaran, kerendahan hati, atau ketaatan. Ketika kita takut kepada Allah, pengendalian diri muncul. Iman diperlukan untuk takut akan Tuhan. Jadi kita mulai dengan iman dan kemudian takut akan Tuhan, yang membawa pengendalian diri, yang membawa kesabaran, kerendahan hati, dan ketaatan.

\section{Menyangkal Diri untuk Patuh dengan Kehendak Allah}

Menjadi murid Yesus berarti siap untuk menderita menurut kehendak Allah. Apa yang dimaksud dengan menderita menurut kehendak Allah? Dalam bahasa aslinya ró $\sigma \chi 0 v \tau \varepsilon \varsigma$ atau menderita berarti, sebuah kondisi seseorang yang memiliki beban karena melakukan perbuatan atas dasar kebenaran. Artinya menahan kesakitan badani maupun rohani untuk menaati hukum kasih Allah (1 Ptr. 4:19). Penderitaan yang dimaksud adalah sebuah penderitaan yang disebabkan bukan karena melakukan kejahatan melainkan kebaikan bagi sesama, sehingga menghasilkan ketaatan kepada Allah (1 Ptr. 3:17; 4:15). Seorang Bapa Gereja bernama Clement dari Alexandria menegaskan: "Because he said, 'In the end, all must agree, have compassion for one another; brotherly love, merciful, humble and so on', to inherit a blessing" (Alexandria, n.d.). Jadi, penderitaan adalah tindakan kasih kepada Allah yang telah memberikan keselamatan melalui
Kristus yang mati dan bangkit untuk mengalahkan dosa (1 Ptr. 5:10; 3:18).

Kehendak Tuhan berarti bahwa semua orang diselamatkan: Ini baik dan menyenangkan Tuhan, Juruselamat kita, yang ingin semua orang diselamatkan dan mengetahui kebenaran. (1 Tim. 2:3-4). Namun, keegoisan terkadang membunuh moral yang berlaku dalam bersosialisasi dengan sesama. Sikap gampang tersinggung dapat memicu sebuah pertengkaran bahkan menghasilkan penganiayaan apabila tidak dikontrol dengan baik. Oleh karena itu, penyangkalan diri penting untuk dilakukan agar sikap egois yang menguasai diri sendiri tidak mengalahkan kerendahan hati.

Fokus utama dalam diri ketika memberitakan Injil adalah memperkenalkan pribadi Kristus yang mengosongkan dirinya untuk menjadi serupa dengan manusia. Penderitaan yang dialami Kristus menjadi contoh nyata bahwa sebuah penganiayaan tidak dapat terhindarkan. Berbagai macam godaan termasuk penganiayaan, Dia hadapi dengan kebenaran firman yang penuh kuasa atas Iblis. Sebelum berperang menghadapi penganiayaan, Kristus berdoa terlebih dahulu kepada Tuhan untuk menghadapi pergumulan yang akan dihadapi. Oleh karena itu Kristus berdoa di taman Getsemani, "Ya Bapa-Ku jikalau cawan ini tidak mungkin lalu, kecuali apabila Aku meminumnya, jadilah kehendak-Mu!' (Matius 26:42). Pada saat yang bersamaan Ia juga berharap kemungkinan tersedianya solusi lain selain mati di atas kayu salib (Boehlke, 1994, p. 30).

Dalam lubuk hati yang paling dalam Yesus sangat sedih dan hancur hati ketika mengetahui bahwa Dia akan mati di atas kayu salib. Dengan menyerahkan semua pergumulan-Nya kepada Bapa serta menggenapi rencana keselamatan, maka Kristus rela mati untuk mengalahkan kutuk, dosa serta maut bagi keselamatan jiwa manusia. Apabila Kristus memprioritaskan diri-Nya dan tidak menggenapi karya keselamatan dari Allah, maka 
manusia akan selamanya dihukum dalam gelapnya maut (Rm. 6:23). Dengan demikian Kristus tetap menjalankan ketaatan-Nya kepada Allah bagi keselamatan jiwa di dunia.

$$
\text { Penyangkalan diri yang dilakukan }
$$

Kristus, hanyalah untuk menggenapi rencana keselamatan Allah. Meski mengetahui bahwa semua kehendak Allah tidak ada yang mudah untuk dilakukan, Kristus rela menyangkal diriNya untuk tunduk pada aturan Allah. Bahkan ketika Dia berinkarnasi menjadi manusia dan lahir ke dunia dengan kondisi keluarga yang sangat sederhana (Yoh. 1:14). Hal ini membuktikan bahwa Yesus telah meninggalkan kenyamanan di surga yang tidak dapat dimilikiNya ketika berada di dunia. Melakukan apa yang Yesus lakukan adalah melakukan apa yang Tuhan inginkan. Hidup seperti Kristus adalah hidup yang menemukan Logos atau Sabda Tuhan dalam Simbol-simbol yang lahir dalam hati atau pikiran kita untuk menjadi benih Tuhan dan kita disebut anak-anak Tuhan (Hendi, 2019, p. 154). Demikian juga yang harus dilakukan oleh seorang misionaris, mereka perlu mengosongkan dirinya agar sama dengan para pendengar yang ingin mendengarkan Injil.

\section{Berdoa serta Berjaga-jagalah}

Untuk menantikan kedatangan Kristus kedua kalinya, kita membutuhkan sikap hati serta berjaga-jaga. Hal ini dilakukan karena, Kristus datang seperti pencuri dan tidak ada seorang pun yang mengetahuinya. Demikianlah seorang penginjil juga menghadapi ancaman bahaya yang tidak diketahui layaknya seorang pencuri yang sudah mengintai nyawanya. Oleh karena beberapa orang maupun kelompok menentang kehadiran penginjil maupun warta Injil yang akan dikabarkan, maka penting bagi seorang penginjil untuk berdoa dan berjagajaga. Meski terlihat biasa dan terlalu rohani, tetapi kekuatan yang dihasilkan dari strategi berdoa dan berjaga-jaga memiliki dampak yang besar dan berpengaruh terhadap penginjilan.
Seperti yang terjadi pada 25 April 1852, Geissler dan salah satu rekannya berangkat dengan kavaleri bersama pendeta O. G. Heldring dan mereka berada di sana selama dua bulan. Heldring adalah penggerak dalam bidang penginjilan Zending di daerah-daerah bangsa yang tidak percaya kepada Tuhan. Belakangan, mereka juga bertemu dengan misionaris C. W. Ottow. Pada malam 26 Juni 1852, mereka dimuat ke kapal Abel Tasman dan berangkat dari Rotterdam ke Batavia (sekarang Jakarta). Namun sebelum menaiki Abel Tasman, mereka berdoa bersama dan dengan senang hati menikmati pemeliharaan kuasa tangan Tuhan (Kriting, n.d.). Inilah yang menjadi kekuatan dan harapan bagi seorang penginjil untuk mempersiapkan diri menghadapi risiko yang akan dihadapi.

Selain itu berdoa merupakan nafas hidup orang percaya. Kalimat ini menjadi inti dari kehidupan rohani seorang penginjil untuk menjaga diri ketika bahaya mengancam serta persiapan diri untuk menjalani kehidupan penginjilan. Berdoa juga menjadi sumber kekuatan bagi jiwa yang telah lelah dan putus asa akan keadaan dan kondisi tempat penginjilan. Sebuah doa yang singkat untuk berjaga-jaga diterapkan oleh Bapa-bapa Pbilokalia dalam kehidupan sehari-harinya ketika menjadi biarawan. Philokalia adalah sebuah kumpulan tulisan yang dicantumkan oleh Bapa-bapa Gereja dari abad keempat sampai kelima yang berasal dari tradisi Kristen Ortodoks (Hendi, 2018, p. 2). Kehidupan rohani Ortodoks atau peninggalan bersejarah ini harus diteladani dari orang-orang suci (Coniaris, 1998, pp. 4-5). Dalam kehidupan Philokalia terdapat istilah orang suci atau dikenal dengan Bapa-bapa gereja yang hidup untuk menjadi serupa dengan Allah. Tujuan mereka membiara ialah untuk menemukan kebenaran dan arti kehidupan yang sesungguhnya. Berbagai aktivitas yang dilakukan adalah berpusat kepada kehendak Allah dari pada dunia. Sehingga kehidupan membiara penuh dengan kondisi yang sangat 
sederhana dan terpencil dari zona nyaman. Selain mendekatkan diri dan mencari kebenaran tentang Allah para biarawan juga melaksanakan praktik kerohaniannya sebagai biarawan yaitu beribadah, berpuasa, berdoa serta berjaga-jaga. Doa merupakan makanan rohani para biarawan dalam menjalani kehidupannya sehari-hari. Salah satu doa yang diajarkan oleh Bapa Gereja St. Theopan berjudul doa Puja Yesus yang berbunyi demikian: "Lord Jesus Christ Son of God have mercy on me" (Coniaris, 1998, p. 45). Doa ini merupakan doa yang dipanjatkan oleh bapabapa gereja serta para biarawan untuk berjagajaga serta melakukan aktivitas sehari-sehari. Doa ini dimaknai, supaya manusia selalu meminta belas kasihan dari Allah serta berharap penuh kepada Allah. Allah tidak toleransi dengan pelanggaran (dosa) tetapi Ia juga mencintai manusia yang telah sadar dan kembali kepada-Nya karena Dia adalah cinta (Hendi, 2018, p. 10).

Melalui doa puja Yesus yang dipanjatkan para biarawan, diharapkan menjadi kekuatan untuk menjalani kehidupan rohani biara yang jauh dari dunia. Seperti yang dikatakan oleh Joseph M. Stowell bahwa doa dalam perspektif manusia seharusnya adalah sebuah kewajiban atau kebutuhan dan bukan sebuah pertimbangan (Stowell, 2000, p. 27). Oleh karena itu kiranya doa menjadi gaya hidup oleh orang percaya terkhusus bagi para penginjil. Doa ini juga sangat relevan dipanjatkan ketika para penginjil atau misionaris melaksanakan penginjilannya, serta menjadi latihan rohani yang membuat kehidupan rohani seorang penginjil untuk mengikis kedagingannya untuk menjadi segambar dan serupa dengan Kristus.

\section{Strategi Eksternal: Membangun Kesetaraan Sosial}

\section{Belajar Mengasihi Masyarakat Suku Terabaikan}

Perbuatan baik merupakan praktik yang dikerjakan oleh murid Kristus sebagai bentuk mengasihi Allah. Mengapa? Untuk mengasihi Allah yang tidak kelihatan, murid Kristus harus bisa mengasihi sesamanya yang kelihatan dengan melakukan kebaikan atau kebenaran. Mengasihi dapat diwujudnyatakan seperti melatih diri untuk tetap sabar, murah hati, tidak cemburu, tidak memegahkan diri, tidak sombong, tidak melakukan yang tidak sopan, tidak mencari keuntungan diri sendiri, tidak pemarah, tidak menyimpan kesalahan orang lain, tidak bersukacita karena ketidakadilan, tetapi karena kebenaran (1 Korintus 13:4-7). Agustine of Hippo menegaskan, "The reason why love does not envy is because it is not puffed up. For where puffing up precedes, envy follows, because pride is the mother of envy." (Augustine, 2021). Hal ini membuktikan bahwa murid Kristus yang dapat mengasihi sesamanya harus menurunkan sikap kecemburuannya. Kecemburuan menjadi awal lahirnya sebuah kesombongan sehingga melahirkan sebuah dosa. Dosa artinya tindakan yang bertentangan dengan perbuatan baik sehingga harus dikikis atau dimatikan. Clement dari Roma menegaskan, "Love beareth all things, is long-suffering in all things" (Alexandria, n.d.). Kasih dapat menjadi dasar untuk melakukan perbuatan baik sehingga Allah dapat mencurahkan anugerah-Nya kepada murid Kristus. Jadi, kasih menjadi solusi utama untuk melawan dosa atau pelanggaran.

Adapun hal yang menjadi penghalang murid Kristus menjalani perbuatan baiknya di dunia adalah tidak semua orang dapat merespons perbuatan baik. Murid Kristus dapat merespons perbuatan baik dengan murid yang lain dikarenakan telah mengenal Kristus yang juga melakukan perbuatan baik. Rasul Paulus yang merupakan rekan Rasul Petrus dapat melakukan kebenaran atau perbuatan baik karena ia telah mengenal Kristus. Jika ditelusuri kehidupan sebelum ia menjadi murid Kristus, dia adalah pribadi yang sangat membenci murid-murid Kristus dan berniat 
untuk membunuhnya. Tetapi, semua itu berubah ketika Tuhan menangkap jiwanya untuk diserahkan dalam perbuatan baik. Sehingga, Rasul Paulus harus menderita oleh nama Kristus. Kini, ia telah bertobat dan menjadi murid Kristus yang berani dan setia (Kis.9:1-19). St. Makarios menyatakan,

Even this life the Lord reveals himself to the soul and is discovered by it, in knowledge and wisdom and love and faith. He placed within the soul understanding and comprehension, volition and the overseeing guidance of the spiritual intellect, and he established within it a great and different kind of subtlety. For God made the soul able to move wherever it wills, made it something that is both volatile and inexhaustible. He gave the soul grace to come and go in an instant, and to serve him in all the range of its intellective powers, in whatever place theSpirit wishes. In short, he made the soul like this so that it could be his own bride, and that it might have communion with Divine, to be merged in union with God, and so becomes as one spirit with God. It is as scripture says: "Whoever is joined to the Lord is made one spirit with him (1 Cor. 6:17)" (Mcguckin, 2020, p. 138).

Jadi, perbuatan baik dapat dimulai dari dalam. Membereskan hati untuk di kikis dari rasa cemburu yang mendatangkan dosa. Awal yang baik untuk mengisi hati ini dengan firman Allah. Kemudian menumbuhkan sikap kasih Allah baik dalam pikiran, perkataan maupun perbuatan untuk menjadikannya sebagai gaya penginjilan di daerah suku terabaikan. Serta merespons kasih Allah melalui perbuatan baik dengan pertobatan yang terus menerus dikerjakan secara berkelanjutan kepada Allah. Sehingga mendatangkan keselamatan adalah cara terbaik yang dapat dipersembahkan kepada Allah yang penuh kuasa untuk misi penyelamatan bagi seluruh umat di dunia ini.
Aplikasi yang dapat diterapkan ketika hati telah dijaga adalah menerapkan tindakan perbuatan kasih kepada suku terabaikan. Dengan mengetahui latar belakang suku terabaikan yang jauh dari kehidupan yang berkecukupan atau dapat dibilang dalam keadaan miskin. Gutierrez mengatakan bahwa orang miskin adalah orang yang keluarganya hanya memiliki setengah gaji dari rata-rata upah nasional selama kurang lebih setahun (Gutierrez, 1974).

Mengasihi sesama dalam konteks penginjilan pada suku terabaikan memang tidak mudah namun dapat dilakukan dengan memperhatikan tempat atau lingkungan yang menjadi sasaran atau lokasi untuk menginjil misalnya jika seorang misionaris hendak menginjil di area suku terabaikan salah satu contohnya di Papua atau lokasi yang sangat terpencil, hal-hal yang harus diperhatikan seperti:

1. Dimulai dari tutur kata serta tindakan yang tidak menyinggung perasaan warga setempat.

2. Mempelajari lokasi dan lingkungan suku terabaikan tersebut mulai dari sejarahnya sampai aturan yang berlaku di tempat tersebut.

3. Memiliki hubungan yang baik kepada ketua adat suku terabaikan setempat, hal ini berguna untuk memperoleh motivasi pendekatan kepada masyarakat.

4. Menggunakan pakaian yang sederhana dan tidak berlebihan.

5. Menghargai keterampilan dan kemampuan masyarakat suku terabaikan dan tidak menganggap enteng dari segi pendidikan.

6. Beri kesempatan suku terabaikan untuk percaya kepada orang yang telah ia kenal (orang suku terabaikan asli) untuk memperkenalkan Kristus kepada masyarakat lainnya.

7. Jangan menjadi batu sandungan bagi suku terabaikan saat terjadi pemihakan atau perselisihan. 
8. Menjadi teladan bagi masyarakat suku terabaikan dengan berpedoman kepada Yesus Kristus yang hanya bertujuan untuk memberitakan Injil bukan yang lain.

9. Memiliki tujuan akhir yaitu mengarahkan sebagian keluarga untuk berkembang menjadi satu jemaat atau gereja.

10. Pengarahan dan pengajaran dari Injil haruslah konsisten dalam naungan majelis misi sehingga masyarakat dapat bergerak utuh sebagai gereja (Ellis, 2005, pp. 147-148).

Mengasihi tidak selalu dengan memberi sesuatu kepada orang lain. Mengasihi juga dapat disalurkan dengan mendoakan atau membangun hubungan yang harmonis terhadap sesama khususnya di area suku terabaikan. Karakter yang baik menentukan nilai atau moral dari perilaku seseorang sehingga ini merupakan hal yang menjadi dasar untuk dipegang oleh seorang penginjil atau misionaris.

\section{Memperbaiki Kesejahteraan Suku Terabaikan}

Pentingnya misionaris untuk menyadari bahwa memperbaiki kesejahteraan masyarakat suku terabaikan sangat berpengaruh terhadap penginjilan. Prinsip penting yang dapat dipegang bagi seorang penginjil ialah misi dalam konteks budaya di suku terabaikan. Hal ini tidak dapat dimengerti hanya mengatakan pandangan usaha memenangkan jiwa dengan cara penginjilan tentang Anak Allah, seperti "pergilah" ataupun "saat kamu pergi." Obrempong mengatakan bahwa misi gereja dalam konteks Alkitabiah jelas memiliki dua tujuan. Ini untuk mencapai jiwa, serta memiliki rasa tanggung jawab kepada sesama (Nkansah-Obrempong, 2017, pp. 280-294).

Beberapa Injil Sinoptik, seperti Injil Lukas menunjukkan ruang sosial pelayanan yang dijalani Anak Allah. Faktor sosial dari pelayanan Kristus menyebar di beberapa bagian Injil Lukas. Berfungsi sebagai ilustrasi untuk pelayanan Yesus, Lukas 4:16-30 menjelaskan pengajaran Kristus dan kepedulianNya terhadap jemaat.Sepanjang konteks Injil Lukas, dengan demikian menjelaskan mengapa Ia harus memberitakan Injil dan menolong sesama manusia. Firman Tuhan dalam Injil Lukas 4:18 menyatakan Kristus mendapatkan kekuatan untuk menyampaikan firman-Nya bagi jemaat yang belum mengenal Allah. Namun, murid-murid-Nya, harus menerima kuasa Roh Kudus sebelum memulai pelayanan (Kis. 2:1-13) yang merupakan penyataan dari nubuat Kis. 1:8. Keduanya secara jelas menjelaskan bahwa pentingnya bermisi dan membangun kesetaraan sosial dalam lingkungan masyarakat. Tuhan Yesus menjadi sosok teladan utama yang harus diikuti para murid untuk memberitakan Injil dan membangun kesetaraan sosial jemaat-Nya dan para murid-Nya (Luk. 4:18-19) selain itu mereka juga membantu jemaat dalam bidang kebutuhan jasmani dan rohani (Kis. 2:44-45; 4:3237) (Susanto, 2019, p. 40).

Untuk menghadapi penganiayaan yang terjadi, saat ini diperlukan pola pikir yang luas untuk mencari solusinya, termasuk melihat faktor luar atau eksternal yang mempengaruhi sikap dalam menghadapi penganiayaan. Berbagai macam penganiayaan dihadapi dengan kondisi yang tidak sama. Beberapa orang merasa putus asa ketika dianiaya bahkan menyerah. Penganiayaan akan membuat pribadi seseorang akan merasa terpuruk (Bora, 2020).

Salah satu faktor eksternal yang mempengaruhi penganiayaan adalah adanya perbedaan kesetaraan sosial. Hal ini menyangkut Kehidupan manusia dalam bidang ilmu pengetahuan, politik, ekonomi, kemasyarakatan, budaya, hukum, pertahanan dan keamanan negara. Kesetaraan sosial merupakan sebuah kondisi pada saat semua orang dalam 
masyarakat secara menyeluruh maupun kelompok yang terisolasi serta memiliki status yang sama dalam faktor-faktor tertentu. Faktorfaktor ini termasuk hak sipil, kebebasan berekspresi, hak kepemilikan, dan memiliki akses yang sama ke barang dan jasa sosial tertentu (Budaya Umum Thpanorama, n.d.)

Kesetaraan ini belum stabil sejak Indonesia merdeka selama 76 tahun, berbagai pelosok Indonesia masih belum terjamah fasilitas serta teknologi yang dapat menunjang kehidupan masyarakat Indonesia. Salah satu contoh yang ditemukan di kampung Lalakon, distrik Eipomek, kabupaten Pegunungan Bintang, provinsi Papua belum tersentuh dengan baik dalam segala hal. Di distrik Eipomek yang terdiri dari 14 desa ini masih belum tersedia segala fasilitas umum yang ada di kota seperti: jalan raya beraspal, jembatan besi, rumah beton atau seng, mobil, motor, listrik. Segala sesuatu yang ada di kota $90 \%$ belum ada di pedalaman ini. Selain itu, juga sangat dibutuhkan pendidikan (PAUD, TK, SD, SMP dan SMA) yang baik, puskesmas yang memadai dalam segala hal sesuai kebutuhan warga setempat, sembako yang harganya bisa terjangkau, alat-alat bertani (sekop, parang, linggis, cangkul, dll.) (Mengenal Distrik Eipomek, Papua., n.d.).

Masyarakat pedalaman Eipomek sangat berharap kepada pemerintah untuk menolong masyarakat dalam menghadapi kemiskinan. Selain itu para penginjil juga memiliki pergumulan untuk membantu masyarakat supaya tidak tertinggal oleh kecanggihan zaman saat ini. Di era digital saat ini apalagi di kota-kota fasilitas memadai seperti kendaraan pribadi, telepon genggam, bahkan rumah sudah menjadi hal yang lumrah dimiliki. Oleh karena itu, diperlukan bantuan dan edukasi bagi masyarakat untuk mengembangkan potensi mereka, salah satunya di bidang pertambangan yang menjadi mata pencaharian utama masyarakat di Papua (Portal Informasi Indonesia, 2019). Dengan adanya perbaikan sistem perekonomian ini dipercaya akan cukup membantu menunjang kehidupan masyarakat lokal. Selain itu, perlu diadakan pengiriman bantuan guru yang kompeten dan berstrata satu untuk menolong pendidikan yang masih tertinggal di daerah ini.

Sebagai calon atau misionaris yang dipanggil untuk memberitakan Injil, dibutuhkan pelayanan diakonia. Sebaiknya para misionaris sudah terlatih terhadap pelayanan ini. Pelayanan diakonia wajib melihat dari perspektif panggilan untuk menolong kehidupan masyarakat yang ingin percaya kepada Kristus dan tidak hanya dipandang sebagai kewajiban atau formalitas sebagai umat Kristiani (Susanto, 2019, p. 51).

\section{Melatih Kemandirian}

Salah satu masalah utama adalah kurangnya pelatihan kejuruan di daerah miskin. Pengupayaan dengan adanya sebuah Sekolah kejuruan, koperasi dan pelatihan manajemen keuangan akan mengarah pada masyarakat yang stabil secara ekonomi. Selain itu, masalah penindasan, eksploitasi dan ketidakadilan harus diperhitungkan. Mikha 6:8 mengatakan umat Tuhan harus bertindak benar dan melindungi hak-hak orang miskin (bdk. Ams. 31:8-9). Dalam menegakkan keadilan, sering kali keterlibatan dalam politik tidak terhindarkan. Meski demikian, kita berjanji untuk tidak menyetujui ideologi politik apa pun kecuali keadilan dan kebenaran tentang Kerajaan Allah. Hikmat dan perhatian sangat dibutuhkan untuk masyarakat seperti ini, akibat dari terasingnya mereka dari kehidupan modern seolah-olah mereka berbeda dan tidak perlu untuk diperhatikan. Di sinilah para misionaris harus memiliki kreativitas dalam membimbing mereka. Transformasi ekonomi harus menjadi pusat perhatian untuk pelayanan kepada masyarakat miskin, karena ini adalah sesuatu yang harus segera ditangani. Tidak akan cukup untuk menyelamatkan jiwa seseorang jika lingkungan akhirnya memaksa mereka untuk 
berbuat dosa lagi (Tarore, 2020).

Untuk menciptakan sebuah kesetaraan sosial, dibutuhkan beberapa elemen yang menukung seperti kekreativitasan dalam menyusun ide untuk menciptakan lapangan kerja bagi masyarakat yang masih jatuh dalam kemiskinan. Kemiskinan memiliki pengertian yang beragam namun, selalu dihubungkan dengan faktor ekonomi. Edi Soeharto mengatakan, "Kemiskinan pada dasarnya merujuk pada kondisi yang menderita dan tidak mampu menunjang kebutuhannya serta konsekuensi ketidakberdayaan negara maupun rakyat menyerahkan keselamatan rakyatnya" (Soeharto, 2009, p. 16).

Oleh karena itu dibutuhkan sebuah kekreativitasan untuk menciptakan sebuah terobosan dalam menangani kemiskinan. Dalam bukunya The Power of Creativity Peng Kheng Sun menyatakan bahwa, Tuhan memberi manusia kemampuan untuk mencipta. Selain manusia, tidak ada ciptaan Tuhan yang memiliki kemampuan untuk menciptakan, termasuk malaikat sekalipun (Sun, 2010, p. 9). Untuk itulah manusia yang dipenuhi dengan ide-ide yang kreatif dapat menjadi penolong untuk Anda dan orang lain. Semua orang berpeluang menciptakan ide yang menarik dan membangun kesetaraan sosial. Sun juga menegaskan, Sejak krisis moneter terjadi di Indonesia, pengangguran terus melonjak karena banyak perusahaan melakukan PHK terhadap para karyawannya. Bagi orang yang memiliki kreativitas, dipecat bukan berarti mereka harus tidak bekerja. Mereka akan memanfaatkan kreativitasnya untuk membuat beberapa lowongan kerja yang bisa memperkerjakan kembali orang yang menganggur. Sehingga tidak perlu lagi menantikan adanya lowongan kerja lagi (Sun, 2010, p. 24).

\section{DAFTAR RUJUKAN}

Alexandria, C. O. (n.d.). Catena Bible. https:// catenabible.com $/ 1 \mathrm{pt} / 3$

Augustine. (2021). Angustine of Hippo on John
Dalam melaksanakan sebuah ide yang kreatif dibutuhkan orang-orang yang handal untuk merealisasikan ide tersebut. Oleh karena itu dibutuhkan kekompakan atau kerja sama yang baik dari beberapa pihak. Selain itu kerja sama dapat membuahkan kemenangan. Syarat utama supaya tidak kalah dalam perang adalah dengan adanya kekompakan atau kerja sama (Boediprayitno, 2020, p. 134). Dibutuhkan usaha yang kompak untuk membantu kesejahteraan masyarakat suku terabaikan.

\section{KESIMPULAN}

Strategi penginjilan membuat para penginjil ikut serta merencanakan segala rencana yang telah ditimbang dan dipikirkan. Dengan memiliki kerendahan hati, penyangkalan diri, dan berjaga-jaga menjadikan seorang penginjil memiliki hati sebagai seorang hamba yang ingin menaati hukum kasih Allah serta menyebarkan kabar gembira bagi semua orang termasuk orang-orang di daerah terpencil seperti suku terabaikan. Penganiayaan memang tidak dapat terhindarkan dari konsekuensi untuk bermisi, namun untuk menghadapi penganiayaan yang terjadi baik secara fisik maupun psikis dibutuhkan sebuah strategi yang melihat dari perspektif eksternal (luar) maupun internal (dalam).

Selain itu, penginjil juga memiliki tanggung jawab untuk membantu sesama dengan meningkatkan kesetaraan sosial masyarakat di suku terabaikan. Dengan demikian seorang penginjil harus menyediakan keterampilan atau keahlian dalam menunjang kehidupan baik ekonomi yang rendah maupun sedang. Serta meningkatkan pengetahuan akan perkembangan teknologi dari masyarakat yang tertinggal jauh dari kemajuan zaman ini.

13:33 - Catena Bible \& Commentaries. http:/ / catenabible.com/com/ 584c89a19ac03ecd4b8e5e44

Budaya Umum Thpanorama: Jadikan diri Anda lebih 
baik bari ini! (n.d.). https:// id.thpanorama.com/articles/culturageneral/30-ejemplos-de-igualdadsocial.html

Boediprayitno, P. (2020). Menuju Hidup Bijak. PBMR ANDI.

Bora, L. N. (2020). Keserupaan Dengan Yesus Dalam Penderitaan, Kesengsaraan Dan Kematian-Nya. Manna Rafflesi, 1. https:// journals.sttab.ac.id/index.php/man_raf/ article/view/127

Coniaris, A. M. (1998). Philokalia: The Bible Of Orthodox Spirituality. Library Of Congress.

Boehlke, R. R. (1994). Siapakah Yesus Sebenarnya? BPK Gunung Mulia.

Soeharto, E. (2009). Kemiskinan dan Perlindungan Sosial di Indonesia. Alfabeta.

Ellis, D. (2005). Metode Penginjilan: Istimewa Tepat Guna bagi Penginjil Awam Praktis dan Taktis. Yayasan Komunikasi Bina Kasih/OMF.

Gutierrez, G. (1974). A Theology of Liberation: History, Politics, and Salvation. SCM Press.

Harefa, M. (2020). Peranan Gereja Mengatasi Kekerasan yang Dialami Remaja dalam Keluarga. MAGNUM OPUS: Jurnal Teologi Dan Kepemimpinan Kristen, 1(2), 112 125. https://doi.org/10.52220/ magnum.v1i2.50

Hendi. (2018). Pertobatan di dalam Philokalia: Artikel Ulasan. Dunamis: Jurnal Teologi Dan Pendidikan Kristiani, 3(1), 52-73.

Hendi. (2019). Inspirasi Kalbu 3. Leutikaprio.

Susanto, H. (2019). Gereja Sebagai Umat Allah dan Rekan Negara. Jafray, Jurnal, 17(1), 3556.

Hidayat, E. A. (2016). Iman Di Tengah Penderitaan: Suatu Inspirasi TeologisBiblis Kristiani. Melintas An International of Philosophy and Religion, 32(3), 285-308. https://journal.unpar.ac.id/index.php/ melintas/article/view/2695.

Jessup, H. H. (1901). Who Ought Not to Go as Foreign Missionaries. Student Volunteer Movement for Foreign Missions.

Kriting, S. (n.d.). Sejarah Masuknya Injil di Tanah Papua. https:// suarakritingfree.blogspot.com/2013/02/ sejarah-masuknya-injil-di-tanahpapua.html
Manurung, K. (2020). Efektivitas Misi Penginjilan dalam Meningkatkan Pertumbuhan Gereja. Dunamis: Jurnal Teologi Dan Pendidikan Kristiani, 4(2), 225233. https://www.sttintheos.ac.id/ejournal/index.php/dunamis/article/view/ 242/166

Dornan, J. \& Maxwell, J. C. (1996). Strategi Menuju Sukses. Network TwentyOne.

Mcguckin, J. A. (2020). Praktikos, Theoretikos, Gnostikos. Leutikaprio.

Mengenal Distrik Eipomek, Papua. (n.d.). https:/ / misisukuterabaikandipapuaindonesia.blog spot.com/2019/08/mengenal-distrikeipomek-papua.html

Zed, M. (2008). Metode Penelitian Kepustakaan. Yayasan Obor Indonesia.

Moeliono, A. M. (1988). Kamus Besar Babasa Indonesia. Balai Pustaka.

Nkansah-Obrempong, J. (2017). Africa's Contextual Realities: Foundation for the Church's Holistic Mission. International Review of Mission, 106(2), 280-294. https:/ / doi.org/10.1111/irom.12186

Pane, F. A. P. (2006). Mendefinisikan OPM dan KKB. Republika.Co.Id. https:// www.republika.co.id/berita/pjad4n440/ mendefinisikan-opm-dan-kkb

Portal Informasi Indonesia. (2019). Ekonomi Papua Masih Bergantung pada Freeport. https://indonesia.go.id/narasi/indonesiadalam-angka/ekonomi/ekonomi-papuamasih-bergantung-pada-freeport

Tarore, R. N.. (2020). Strategi Penginjilan dalam Wilayah Masyarakat di Bawah Garis Kemiskinan. https://doi.org/10.31219/ osf.io/dt8y9

Silalahi, J. N. (2019). Konsep Penganiayaan dalam Injil Matius 10:16-33 dan Relevansinya bagi Orang Percaya pada Masa Kini. Voice of Hami, 2(1), 1-14.

Sills, M. D. (2008). Misionary Call: Find Your Place in God's Plan for the World. Moody Publisher.

Stowell, J. M. (2000). Kemenangan Doa. Interaksara.

Liauw, S. (1999). Hakekat Kebebasan Beragama. Graphe.

Sun, P. K. (2010). The Power of Creativity. 
Penerbit Andi.

Hale, T. (1995). On Being a Missionary. William Carey Library.

Tim SINDOnews. (2021). Akademisi Uncen: Penyerangan Misionaris di Papua Pertanda Lenyapnya Perjuangan KKB. https:// nasional.sindonews.com/read/296692/14/ akademisi-uncen-penyerangan-misionarisdi-papua-pertanda-lenyapnya-perjuangankkb-1610305292

Wagner, C. P. (1996). Strategi Perkembangan Gereja. Gandum Mas. 